\title{
Smart Media Audience-type User's Media Service Acceptance: an Empirical Research
}

\author{
Biao Gao \\ Graduate School of Business Administration \\ Kobe University \\ Kobe, Japan
}

\author{
Lin Huang \\ Graduate School of Business Administration \\ Kobe University \\ Kobe, Japan
}

\begin{abstract}
In the current era of smart media, based on active audience theory, this study proposes the concept of the smart media audience-type user, to explain the behavioral characteristics of consumers in smart media content services. Compared with the traditional mass media audience, the smart media audience-type users are actively engaged in the smart media content service process and have three new belief characteristics: two-way communication; personalization; cocreation. This study thus proposes a research model based on the technology acceptance model, and takes the smart media audience-type users' belief characteristics as the antecedents in the extended model. The structural equation modeling results suggest that the model is largely verified. The findings of the research make significant theoretical contributions. In the smart media era, based on active audience theory, the concept of smart media audience-type user was theoretically formed to facilitate a better understanding of their belief characteristics and media service acceptance. This study also has important managerial implications. It should help practitioners better satisfy smart media audience-type users' needs and thus maintain their continuance intentions toward smart service.
\end{abstract}

Keywords-active audience; smart media audience-type user; belief characteristics; extended TAM

\section{INTRODUCTION}

Along with the development of communication technology, profound changes are taking place in media. Smart media based on smart terminals can not only provide effective two-way communication and personalized services for users, but also enable users to participate in the content service.

Smart media can be understood from two perspectives: the technology perspective and the user perspective. From the technology perspective, smart media consists of media, artificial intelligence (AI), communication technology and data [1]. However, from the user perspective, smart media is considered as a user-centric media that can sense the user's different life scenarios, and thus provide users with the corresponding service [2]. This paper explains smart media service and user behavior based on the user perspective.

Smart media can be seen as a marketplace where online content service is traded, but it is very unique in comparison with a conventional marketplace. Also, the consumer who consumes the content service in this market is very special.
No previous research has explicitly indicated what kind of consumer it is, what belief characteristics toward smart media service features do they have, and how are their behavioral intentions influenced by those belief characteristics. However, there is an existing theory to explain this.

Active audience theory argues that media audiences do not just receive information passively, but are actively involved. Evidence in the field of audience research has shown that audiences do not only receive information passively, they also take the initiative to choose media channels and even begin to create media content by different means [3]. Newer media users tend to be increasingly more active, more selective, self-directed, receivers as well as producers of content [4]. Based on the active audience theory, review of the evolution of the media audience, this paper conceptualizes a special kind of content service consumer as a smart media audience-type user.

This article studies the users of AI enabled smart TV (AI TV), to explore smart media service and user belief characteristics. As a typical smart media, AI TV combines AI with ordinary smart TV. AI TV has natural language understanding capabilities; it can adjust internal algorithms by collecting an individual user's viewing behavior data to provide personalized content service; it also facilitates users to co-create content.

Based on active audience theory, this study seeks to understand the concept of smart media audience-type user, their belief characteristics and media service acceptance. Thus, the purpose of this paper is as follows:

- To understand the concept of the smart media audience type user;

- To understand the belief characteristics of the smart media audience-type user;

- To explore the smart media audience-type user's media service acceptance. 


\section{THEORETICAL FRAMEWORK}

\section{A. The Development of Audience Theory}

The concept of media audience originated from the audiences of sports games, philosopher's speeches and early public drama and music performances from 2000 years ago. The initial research on audience was made by media groups to predict advertising revenue [5]. The development of audience research can be roughly divided into four stages, as shown in "Table I":

TABLE I. The Four MaIn Stages of AudiEnCE RESEARCH

\begin{tabular}{|l|l|}
\hline \multicolumn{1}{|c|}{ Representative Researchers } & \multicolumn{1}{c|}{ Standpoints } \\
\hline $\begin{array}{l}\text { (Rogerson, 1939; } \\
\text { Lasswell \& Blumenstock, 1939) }\end{array}$ & $\begin{array}{l}\text { Magic bullet theory, and powerful mass media theory, both consider audience as passive } \\
\text { recipients of promotional content, on whom an irresistible effect by mass media is exerted } \\
\text { [6] [7]. }\end{array}$ \\
\hline (Blumer, 1946) & $\begin{array}{l}\text { Introduced sociological concept, and concluded that audiences can be called the masses } \\
\text { characterised by large scale, anonymity, infinity and poor stability [8]. }\end{array}$ \\
\hline $\begin{array}{l}\text { (Lazarsfeld et al., 1950; } \\
\text { Bauer, 1964a; Bauer, 1964b) }\end{array}$ & $\begin{array}{l}\text { The media has only limited effect, researchers believe that the audience is stubborn and can } \\
\text { select and understand information content according to their own needs. However, they } \\
\text { cannot control the release of media content [9] [10] [11]. }\end{array}$ \\
\hline E. Katz \& Blumler (1974) & $\begin{array}{l}\text { Proposed Uses and Gratifications Theory to explore the impact of mass communication on } \\
\text { people from the perspective of the audience's needs and wants [12]. }\end{array}$ \\
\hline
\end{tabular}

\section{B. From Active Audience to Active User}

Based on active audience theory, there are parts of the meaning of "consumer" within the active audience concept. From a behavioral research perspective, the media audience can be considered as an active and motivated set of consumers in charge of their own experience [12]. Along with media evolution, driven by updates in communication technology, internet technology and AI, audience undergoes a process of serization, and turns into an audience-type user. Compared to the traditional mass audience, a smart media audience-type user applies user-centric logic and users' demand "one to one" two-way communication and more personalized content services, they want to participate in the media service and co-create.

\section{Smart Media Audience-type User}

Silverstone (1994) made a comparison between the media as material/technological objects and the media as texts/symbolic messages. The former is based on the analysis of daily media use; the latter is on the basis of an analysis of the audiences' interpretive activities toward particular media texts. As a result, he doubly described audience as a consumer-viewer [13]. From this time on, consistently and continually, media is in perpetual evolution, and so is its audience. The audience is gradually placed at the core of media service.

User, which was originally a concept from economics and marketing, usually refers to consumers and purchasers of products or services in business activities, with the initiative and the right to choose. As traditional mass media first turned into interactive media, and eventually transformed into smart media, the way media service was provided fundamentally changed. As a result, media audience has undergone a process of userization.

In the context of interactive media service and the latest smart media service, the audience has more choices regarding the form and content of the media. In the context of interactive media, the audience can directly choose the content they are interested in, and they can customize the content options. As a result, the process of userization begins with the addition of certain characteristics of the audiencetype user. In the smart media context, smart media based on AI and big data analysis of users, can provide more personalized content services. Based on natural language understanding, smart media can facilitate more natural and effective "one-to-one" two-way communication. Users are also capable of participating in content service co-creation. As a result, the userization process of audience is completed.

In order to explain the new user in smart media content service, in this study, we conceptualize a special kind of smart media content service consumer as a smart media audience-type user. This concept has duality, it refers to a user, who simultaneously consumes smart media as a service and is also an audience of smart media as content. Thus, from an active audience theory approach, we assume that smart media audience-type users are actively involved in determining how they use smart media. They no longer play a passive and subordinate role in the process of content service consumption, instead, they are perceived to have three belief characteristics different from the mass media audience: firstly, they demand "one to one" two-way communication (two-way communication), secondly, personalized content services are needed (personalization); thirdly, they want a share in the power as co-creator in the consumption process (co-creation).

\section{Technology Acceptance Model (TAM)}

Based on the fact that smart media can also be considered as an information system that processes the latest $\mathrm{AI}$ technology, this research explored TAM.

TAM was proposed by Davis (1986) to theorize the usage behavior of computer technology [14]. TAM deconstructs the attitude construct of the rational behavior theory into two variables: perceived usefulness (PU) and perceived ease of use (PEOU). PU is defined as the degree to which a user believes that using a particular system can improve his or her performance. PEOU is defined as the degree to which a user believes that using a particular system does not require effort. Attitude toward using (ATU) can be defined as total evaluations toward performance [14]. 
Intention to use in this study refers to users' continuance intention (CI).

Many researchers have improved the TAM to fit the specific context of the technology they studied. An important improvement to TAM is the addition of social influence factors in predicting users' usage of new technologies [15].

There are many internet media related studies using TAM, for example: Word-of-mouth research on internet [16]; We Chat usage behavior research [17]; user behavior in traditional media clients [18]; internet TV research [19]; and so on.

This study takes belief characteristics of smart media audience-type user as antecedents in our extended TAM to explore their media service acceptance. Based on the relationships within the TAM, the following hypotheses are made:

H1a. PEOU is directly positively related to PU.

$\mathrm{H} 1 \mathrm{~b}$. PU is directly positively related to ATU.

H1c. PEOU is directly positively related to ATU.

$\mathrm{H} 1 \mathrm{~d}$. ATU is directly positively related to $\mathrm{CI}$.

\section{E. Smart Media Audience-type User's Belief Characteristics}

1) Two-way communication: one-way communication media tends to to provide content service in one-way (from the media to the audience). Traditional mass media facilitates "one to many" communication. Two-way communication media supports both "one to one" two-way communication between media and user, and "many to many" communication among users [4]. Two-way communication is interactive, and individual users can respond to the content service provided through the same channels [20]. Typical one-way communication media includes radio and traditional television, and typical twoway communication media is represented by smart media. In this study, we define two-way communication as the twoway exchange of information process between users and AI TV content service in real-time. This is supported by AI functions like natural language understanding. Based on active audience theory, smart media audience-type users have the need for two-way communication, thus the satisfaction of the needs can influence their attitude toward using and perceptions of media usefulness.

2) Personalization: The basic idea of personalization is to provide personalized service to users based on their unique preferences. From no personalization to high personalization, the degree of personalization is different [21]. When customized content service is sent to a particular individual, it is considered highly personalized. If the content service is only designed based on some common characteristics of a subset of the population, it can be considered moderately personalized. If the content service has no specific goal, then it is non-personalized [22]. In this study, the personalization of smart media service is defined as smart media based on big data analysis of users' media habits, and predictions of each user's preferences to provide personalized content services. Based on active audience theory, smart media audience-type users have the need for personalized content services, thus the satisfaction of the needs can influence their attitude toward using and perceptions of media usefulness.

3) Co-creation: With the development of communication technology, audiences have an increasing influence on media content in terms of its creation, production and distribution [23]. In smart media, the distinction between content producers and audience is no longer obvious; the audience is not only a recipient of content service, but also a participant and co-creator. At the content level, smart media facilitates the audience actively participating in the media, and further, at the technical level, the user is given more oppertunities for co-creation. Based on the active audience theory, smart media audience-type users have the need to participate in the media content and play a co-creation role, thus the satisfaction of the needs can influence their attitude toward using and perceptions of media usefulness.

Based on the above discussion, the following hypotheses are made:

H2. Smart media audience-type user's belief characteristics (a) two-way communication, (b) personalization, and (c) co-creation are directly positively related to ATU.

H3. Smart media audience-type user's belief characteristics (a) two-way communication, (b) personalization, and (c) co-creation are directly positively related to PU.

Based on the above discussion, the research model of this study is shown in "Fig. 1":

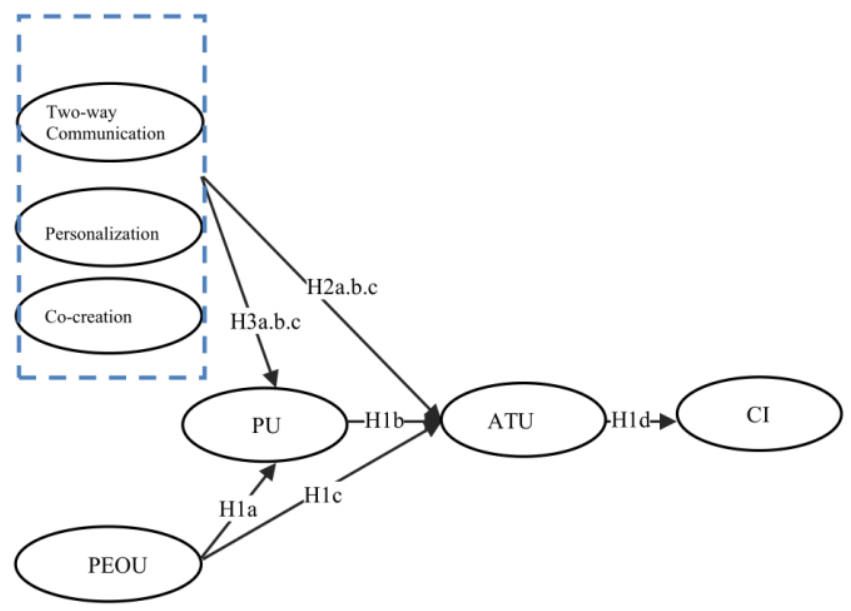

Fig. 1. Research model. 


\section{RESEARCH METHOD}

This study employs a quantitative research approach by using a questionnaire survey. The samples in this study are collected through Baidu sample service in China. Participants are users who have used AI TV service. The questionnaire items were measured using seven-point Likert scales. In this study, the measurement scales were adopted from past literature (Perceived Two-way communication (PTC) [24]; Perceived Personalization (PP) [25]; Perceived Co-creation (PCC) [26]; PEOU [15]; PU [15]; ATU [27]; CI [28]) and adjusted to the context of the current study.

A pilot test was conducted among a small group of users, who were then excluded from the formal survey. This study found pilot test evidence that the measurement scales were valid and reliable. In the main survey, a total of 585 valid samples were collected. Male samples and female samples accounted for roughly $50 \%$ respectively. About $83 \%$ of the respondents were aged between 18 and 35; about $68 \%$ of the respondents earned between 3,000 and 10,000 Yuan (RMB) a month.

\section{RESULTS}

In this study, structural equation modeling (SEM) was used for data analysis using AMOS 21.0.

\section{A. Measurement Model}

In the Measurement model, all factor loadings exceeded 0.6. We also evaluated the validity, including content validity, discriminant validity and convergent validity, to verify the measurement model. The content validity of this paper is based on the review of the existing literature and the measurement scales are verified by other researchers. In addition, tests of discriminant validity of the measurement scales were conducted to analyze the correlation between the measurement scales; the convergent validity was evaluated by testing composite reliability (CR) and average variance extracted (AVE). CR values were all higher than 0.70 and AVE values were all higher than 0.50 , indicating that the measurement model achieved satisfactory results. The statistical results of the measurement model are shown in "Table II" and "Table III" following:

TABLE II. CONVERGENT VALIDITY

\begin{tabular}{|c|c|c|c|c|}
\hline Constructs & Items & $\begin{array}{c}\text { Standardized } \\
\text { Factor Loadings }\end{array}$ & CR & AVE \\
\hline \multirow{3}{*}{ CI } & CI1 & 0.733 & \multirow{3}{*}{0.764} & \multirow{3}{*}{0.519} \\
\hline & CI2 & 0.719 & & \\
\hline & CI3 & 0.71 & & \\
\hline \multirow{4}{*}{ ATU } & ATU1 & 0.835 & \multirow{4}{*}{0.863} & \multirow{4}{*}{0.613} \\
\hline & ATU2 & 0.823 & & \\
\hline & ATU3 & 0.75 & & \\
\hline & ATU4 & 0.717 & & \\
\hline \multirow{5}{*}{ PTC } & PTC1 & 0.631 & \multirow{5}{*}{0.847} & \multirow{5}{*}{0.528} \\
\hline & PTC2 & 0.648 & & \\
\hline & PTC3 & 0.751 & & \\
\hline & PTC4 & 0.785 & & \\
\hline & PTC5 & 0.802 & & \\
\hline \multirow{4}{*}{ PP } & PP1 & 0.704 & \multirow{4}{*}{0.840} & \multirow{4}{*}{0.569} \\
\hline & PP2 & 0.747 & & \\
\hline & PP3 & 0.78 & & \\
\hline & PP4 & 0.783 & & \\
\hline \multirow{3}{*}{ PCC } & PCC1 & 0.77 & \multirow{3}{*}{0.806} & \multirow{3}{*}{0.580} \\
\hline & PCC2 & 0.758 & & \\
\hline & PCC3 & 0.757 & & \\
\hline \multirow{3}{*}{ PEOU } & PEU1 & 0.732 & \multirow{3}{*}{0.808} & \multirow{3}{*}{0.584} \\
\hline & PEU2 & 0.801 & & \\
\hline & PEU3 & 0.758 & & \\
\hline \multirow{3}{*}{ PU } & PU1 & 0.791 & \multirow{3}{*}{0.782} & \multirow{3}{*}{0.545} \\
\hline & PU2 & 0.746 & & \\
\hline & PU3 & 0.673 & & \\
\hline
\end{tabular}

TABLE III. CORRELATION MATRICES AND DISCRIMINANT VALIDITY

\begin{tabular}{|l|c|c|c|c|c|c|c|}
\hline & PU & PEOU & PTC & PP & PCC & ATU & CI \\
\hline PU & $\mathbf{0 . 7 3 8}$ & & & & & & \\
\hline PEOU & 0.645 & $\mathbf{0 . 7 6 4}$ & & & & & \\
\hline PTC & 0.593 & 0.558 & $\mathbf{0 . 7 2 7}$ & & & & \\
\hline PP & 0.575 & 0.580 & 0.650 & $\mathbf{0 . 7 5 4}$ & & & \\
\hline PCC & 0.607 & 0.534 & 0.561 & 0.653 & $\mathbf{0 . 7 6 2}$ & & \\
\hline ATU & 0.636 & 0.596 & 0.622 & 0.624 & 0.581 & $\mathbf{0 . 7 8 3}$ & \\
\hline CI & 0.550 & 0.543 & 0.523 & 0.463 & 0.416 & 0.677 & $\mathbf{0 . 7 2 0}$ \\
\hline
\end{tabular}

a. Note: The values on the diagonal are the square root of the AVE values of each latent variable, and the other values are the correlation coefficients among the latent variables

\section{B. Structural Model}

In the structural model testing, we adopted theorytrimming techniques [29]. According to the theory-trimming techniques, the model was re-tested by removing the insignificant path relations PEOU-ATU, PP-PU, and PCCATU.

The following indices were examined. The chisquare/degree of freedom is $2.533<3$, GFI is $0.908>0.9$; NFI is $0.919>0.9$; CFI is $0.949>0.9$; TLI is $0.941>0.9$; RMSEA is
$0.051<0.08$. The goodness-of-fit indices indicate that the model provided a good fit for the data.

\section{Hypotheses Testing}

First, regarding the path relationships within TAM (H1), which are related to variables, including PU, PEOU, ATU, and CI, all except H1c were supported. Furthermore, regarding the relationships between smart media audiencetype users' belief characteristics and ATU (H2), PTC and PP directly positively affect ATU, so $\mathrm{H} 2 \mathrm{a}$ and $\mathrm{H} 2 \mathrm{~b}$ were 
supported. However, PCC had no significant impact on ATU, indicating that $\mathrm{H} 2 \mathrm{c}$ is not supported. In addition, regarding the relationships between smart media audience-type users' belief characteristics and PU (H3), PTC and PCC directly positively affect PU. Therefore, $\mathrm{H} 3 \mathrm{a}$ and $\mathrm{H} 3 \mathrm{c}$ are supported. But the influence of PP on PU is not significant. Therefore, $\mathrm{H} 3 \mathrm{~b}$ was not supported. The test results of the hypothesis relations in the model are shown in "Table IV":

TABLE IV. HYPOTHESIS TESTING

\begin{tabular}{|l|l|l|l|}
\hline \multicolumn{1}{|c|}{ The hypotheses } & Path coefficients & P values & Support \\
\hline H1a:PEOU-PU & 0.519 & $* * *$ & Yes \\
\hline H1b:PU-ATU & 0.491 & $* * *$ & Yes \\
\hline H1c:PEOU-ATU & n.s & n.s & No \\
\hline H1d:ATU-CI & 0.854 & $* * *$ & Yes \\
\hline H2a: PTC-ATU & 0.249 & $* * *$ & Yes \\
\hline H2b: PP-ATU & 0.178 & $* *$ & Yes \\
\hline H2c: PCC-ATU & n.s & n.s & No \\
\hline H3a: PTC-PU & 0.182 & $* *$ & Yes \\
\hline H3b: PP-PU & n.s & n.s & No \\
\hline H3c: PCC-PU & 0.276 & $* * *$ & Yes \\
\hline \multicolumn{2}{|c|}{ a. } & $* * *: p<0.001, * *: p<0.01, *: p<0.05$.
\end{tabular}

\section{DISCUSSION AND CONCLUSION}

\section{A. Discussion}

This study is conducted to understand the concept of smart media audience-type user and the causal relationships between their belief characteristics and service acceptance. In the research model, the empirical evidence shows that most hypotheses are supported, except for PEOU-ATU (H1c), PCC-ATU (H2c), and PP-PU (H3b).

In testing the hypotheses, PEOU-ATU (H1c) was not empirically supported. However, this can be explained. Based on the fact that smart media service can be accessed easily with friendly interface, this makes smart media very easy to use. Therefore, user's attitude toward smart media service depends primarily on PU. Furthermore, PCC does not have a direct positive impact on ATU (H2c). This can also be explained. At the current stage, the users' co-creation activities, such as bullet comments, tend to interfere with the content service, thus damaging the users' experience. Smart media co-creation is also technologically in its infancy increasing user apathy towards new smart media service, and thus does not lead to a positive influence on their attitudes. In addition, somewhat surprisingly, the effect of PP on PU is not significant. A reasonable explanation might be that in smart media service, personalization is achieved based on smart service recommendation, this is more like a form of marketing based on previous data collection, thus, its impact on PU is not positive. However, it can directly positively impact on ATU.

\section{B. Implication}

Smart media has reshaped the concept of the audience. Smart media marks a new evolutionary form of media and also brings the smart media content service market into a new stage. With the evolution of media forms, the audience goes through a process of userization. This study conceptualizes the new type of media audience as a smart media audience-type user to explain and understand their belief characteristics as well as media service acceptance. A smart media audience-type user consumes smart media as a service and is simultaneously an audience of smart media as content. Smart media audience-type users conform to the logic of user-centered, with belief characteristics including "one-to-one" two-way communication, personalization and co-creation.

The empirical evidence shows that two-way communication, personalization and co-creation are valid antecedents in the extended TAM. Thus, by enhancing smart media audience-type users' belief characteristics, their continuance intention to use smart service can be increased.

The empirical evidence of this study proves that the active audience theory is still applicable to this stage of smart media development. This study thus theoretically develops the active audience theory, and suggests that the userization of traditional audiences results in the formation of the smart media audience-type user from a theoretical perspective. On this basis, this study has preliminarily formed the smart media audience-type user theory in order to understand smart media service acceptance.

This study empirically proves that the belief characteristics of smart media audience-type user can directly positively predict their ATU, thus enhancing the continuance intention to use smart service. Through this study, we know that PP and PTC are two major belief characteristics that can directly predict ATU. Therefore, smart media practitioners can consider enhancing the perception level of personalization and two-way communication to improve users' attitude and continuance intention more effectively and efficiently. Thus, the findings can help smart media service practitioners better satisfy smart media audience-type user's needs and thus maintain their continuance usage intention.

\section{Conclusion}

Based on the user perspective of smart media and the active audience theory, this study provides the concept of smart media audience-type user to explain the special kind of smart media content service consumers' belief characteristics and smart media service acceptance. Using TAM as a reference model, we thus established a theoretical model by taking belief characteristics of smart media audience-type user as antecedents in our extended TAM to explore their media service acceptance. By doing this, this study has furthered the understanding of smart media audience-type users' media service acceptance behavior.

\section{Limitation and Suggestion}

The limitations of this study are reflected in two aspects: First, the sample size is relatively small compared with the large number of AI TV users. Second, this study is a crosssectional study, which can only study a social phenomenon at a specific time and space.

The main feature of smart media service is to meet the personalized needs of users in different life scenarios. Future 
studies should further explore smart media audience-type users' lifestyles, so as to better understand their behavior.

\section{ACKNOWLEDGMENT}

We wish to thank for Otsuka Toshimi Scholarship Foundation for its generous help. We also wish to thank Mr. Don Moore from Kobe University Academic Language and Communication Support for English editing.

\section{REFERENCES}

[1] Shang, Y. Q. (2016). The future of media lies in "intelligence +". Journalism and writing (In Chinese), 2016(1).

[2] Hu, Z. R. (2016). The future development direction of media: constructing an all-media ecosystem. Chinese Broadcasting (In Chinese), (11), 48-52.

[3] Chi, J. X. (2009). The identity convergence of communicators and receivers in the new media era - an analysis of the research path of user-generated content (UGC). The southeast academic (In Chinese), (4), 166-168.

[4] Livingstone, S. (2004). The Challenge of Changing Audiences Or, What is the Audience Researcher to do in the Age of the Internet? European Journal of Communication. 19 (1), p75-86.

[5] McQuail, D (1997). Audience Analysis. London: Sage.

[6] Rogerson, S. (1939). Propaganda in the next war. Foreign Affairs. Arno Press.

[7] Lasswell \& Blumenstock. (1939). World Revolutionary Propaganda: A Chicago Study. Chicago, Ill.: Knopf, p.4-11

[8] Blumler, H. (1946). The mass, the public and public opinion. In A Lee (Ed.), New outlines of the principles of sociology. New York: Barnes \& Noble.

[9] Lazarsfeld, P. F., Berelson, B., \& Gaudet, H. (1950). The people's choice. Eco-Architecture: Harmonisation between Architecture and Nature, 18(Jan)

[10] Bauer, R.A. (1964a). The communicator and the audience. In L.A. Dexter \& D.M. White (Eds.), People, society and mass communication. New York, Free Press.

[11] Bauer, R.A. (1964a). The communicator and the audience. In L.A Dexter \& D.M. White (Eds.), People, society and mass communication. New York, Free Press.

[12] Katz E. \& Blumler J. (1974), The Uses of Mass Communication. Thousand Oaks, CA: Sage.

[13] Silverstone, R (1994). Television and Everyday Life. London: Routledge. p1-199.

[14] Davis, F.D. (1986). A technology acceptance model for empirically testing new end-user information systems: theory and results. Doctoral dissertation. MIT Sloan School of Management, Cambridge, MA.

[15] Venkatesh, V.\& Davis, F.D. (2000). A theoretical extension of the technology acceptance model: four longitudinal field studies. Manag. Sci.. 46 (2), p186-204.

[16] Bi, J. D. (2009). Research on Internet word-of-mouth acceptance based on technology acceptance model. Contemporary economic management (In Chinese),31(9), 33-38.

[17] Kuang, W. B. (2015). Personal privacy protection in the era of big data. Chinese Broadcasting (In Chinese), 52(6), 11-14.

[18] Kuang, W. B. \& Qiu, S. M. (2017). Research on the usage behavior of traditional media client based on technology acceptance model. Modern communications. Journal of communication university of China (In Chinese), 39(1), 128-131.

[19] Wagner, G., Schramm-Klein, H., \& Steinmann, S. (2017). Consumers' attitudes and intentions toward internet-enabled tv shopping. Journal of Retailing \& Consumer Services, 34, 278-286.
[20] Hogan, B., Quan-Haase, A (2010). Persistence and change in social media. Bull. Sci. Technol. Soc. 30(5), 309-315.

[21] Arora, N., Dreze, X., Ghose, A., Hess, J. D., Iyengar, R. \& King, B., et al. (2008). Putting one-to-one marketing to work: Personalization, customization, and choice. Marketing Letters. 19 (3-4).

[22] Hawkins, R. P., Kreuter, M., Resnicow, K., Fishbein, M., \& Dijkstra, A. (2008). Understanding tailoring in communicating about health. Health Education Research, 23(3), 454-66.

[23] Napoli, Philip M. Audience Evolution: New Technologies and the Transformation of Media Audiences. New York: Columbia University Press, 2011

[24] Mcmillan, S. J., \& Hwang, J. S. (2002). Measures of perceived interactivity: an exploration of the role of direction of communication, user control, and time in shaping perceptions of interactivity. Journal of Advertising, 31(3), p29-42.

[25] Kim, Y. J., \& Han, J. (2014). Why smartphone advertising attracts customers: a model of web advertising, flow, and personalization. Computers in Human Behavior, 33(2), 256-269.

[26] Mathis, E. F., Kim, H., Uysal, M., Sirgy, J. M., \& Prebensen, N. K. (2016). The effect of co-creation experience on outcome variable Annals of Tourism Research, 57, 62-75.

[27] Davis, F. D. (1993). User acceptance of information technology: system, user perceptions and behavioral impacts. International Journal of Man-Machine Studies, 38(3), 475-487.

[28] Bhattacherjee, A. (2001). Understanding information systems continuance: an expectation-confirmation model. Mis Quarterly, 25(3), 351-370.

[29] James, L. R., Mulaik, S. A., \& Brett, J.M. (1982). Causal analysis: Assumptions, model and data. Beverly Hills: Sage. 